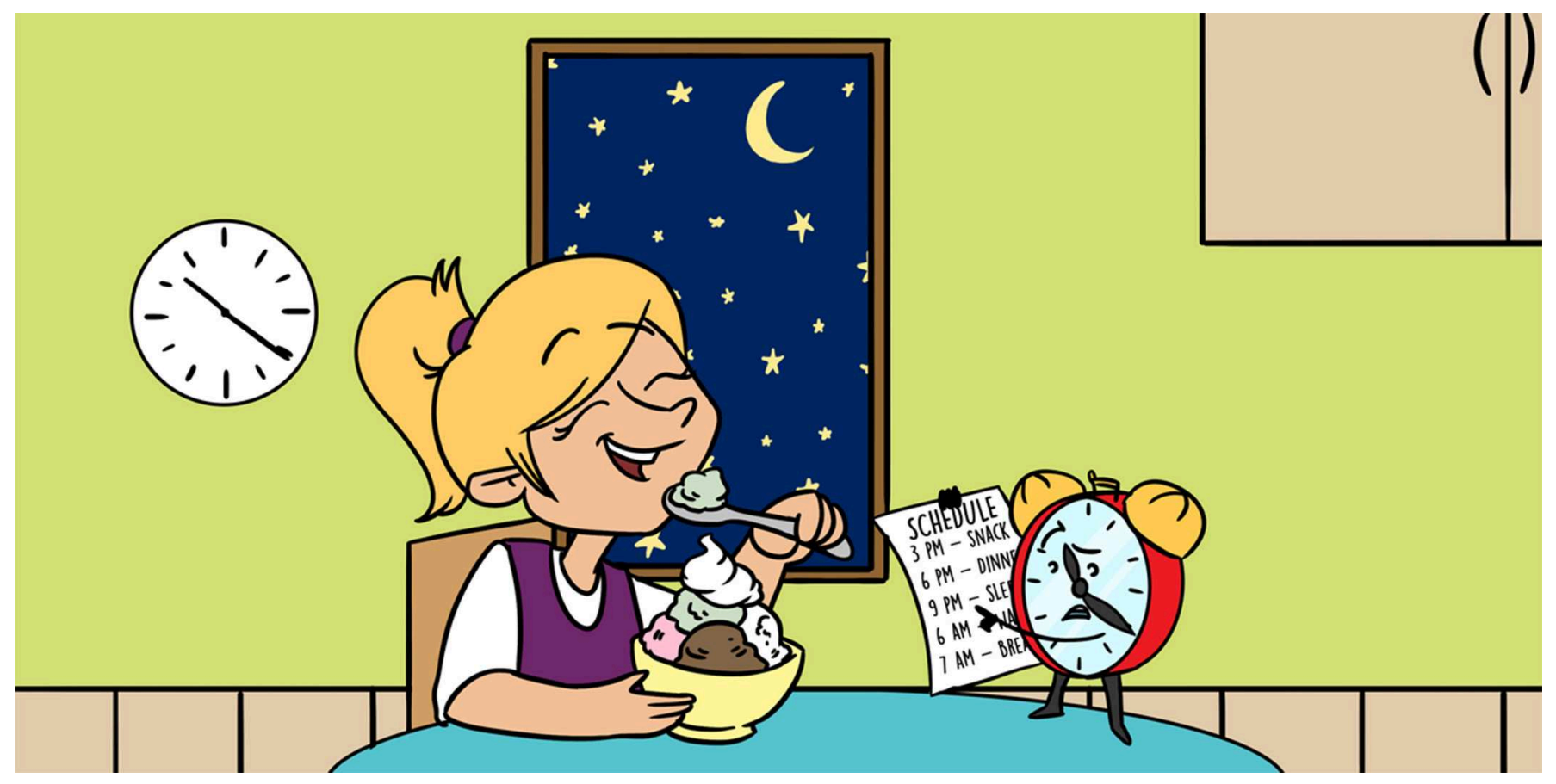

\title{
THE BODY"S CLOCK: TIMEKEEPING WITH FOOD
}

\section{Carolina M. Greco, Kevin B. Koronowski and Paolo Sassone-Corsi *}

U1233 INSERM, Department of Biological Chemistry, Center for Epigenetics and Metabolism, University of California, Irvine, Irvine, CA, United States

\section{YOUNG REVIEWER:}

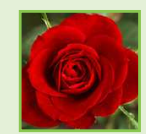

SIENNA

AGE: 15
Have you ever asked yourself why you have energy during the day and feel tired at night? What if I told you that there is a part of your body that is secretly controlling these feelings without you knowing? Well there is! It is called your biological clock or circadian rhythm, and it is ticking away inside you right now. What is really amazing is that your biological clock collects information from the outside world, such as sunlight and food, and sets your body's time to match it. The times when you choose to eat might move your body's clock forwards or backwards, and what you eat can make your clock stronger or weaker. Eating and sleeping are great, but your biological clock does so much more for you. The good news is all you need to do is listen to it and it will help keep you healthy.

\section{YOU HAVE A TICKING CLOCK IN YOUR BODY}

It is morning, so you get up, maybe have breakfast, and feel awake and energetic by the time you get to school. Fast forward $12 \mathrm{~h}$ : now it is the evening and you feel very tired and sleepy. Did you know that your 
Figure 1

Your Body Clock. All life forms-including you-have their own time-keeping systems. The time-keeping system is called a body clock or biological clock. The body clock is in constant communication with the outside world: sunlight is the main message for your clock, but food and exercise also help your body clock keep time. A well-functioning clock will keep you healthy by regulating many bodily functions.

\section{BODY}

CLOCK/BIOLOGICAL CLOCK

The built-in timing system that is part of every living organism.

\section{CIRCADIAN}

\section{RHYTHM}

"Circadian" comes from Latin and means "about a day," referring to a 24-h cycle. These cycles repeat every day, giving rise to a rhythm, like sleeping and waking at about the same times.

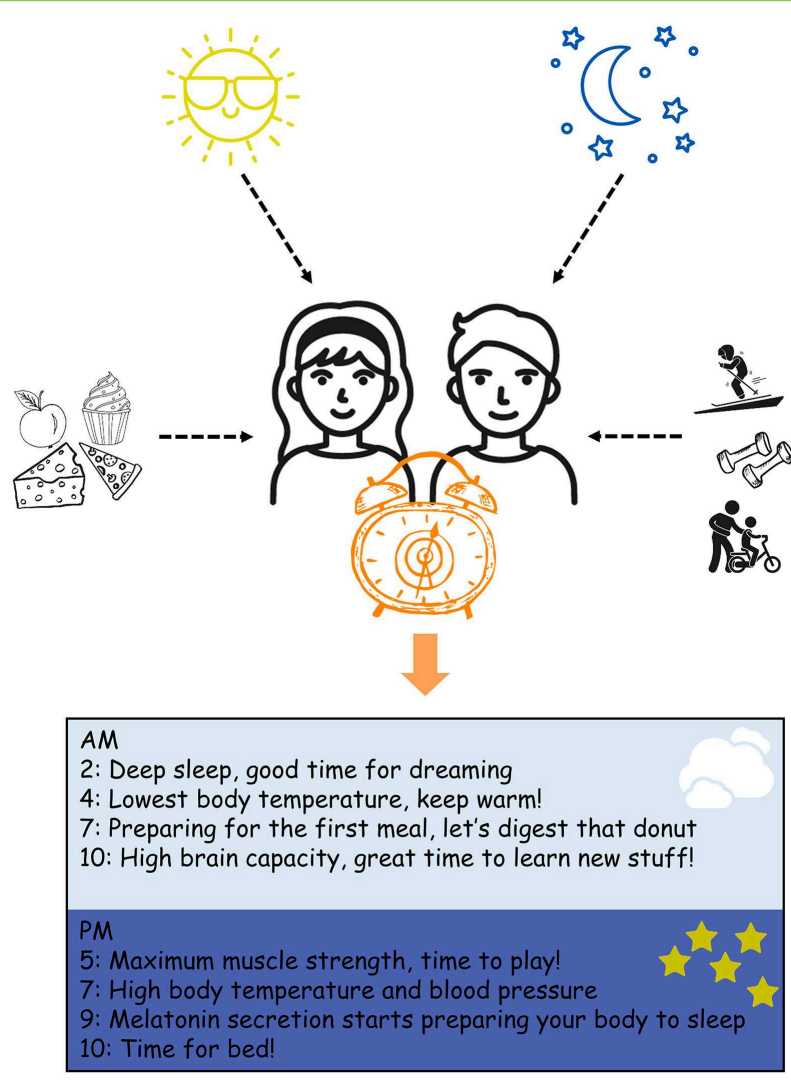

Figure 1

body is secretly controlling these feelings and your sleep schedule without you knowing? Think of this: during the week, your parents shake you awake around $7 \mathrm{a}$.m. If 1 day they forget to, what time will you wake up? Probably around 7 a.m.! How is this possible? How does your body know that it is 7 a.m. and that you should get up? Well, the answer is simple. Each of us has his or her own body clock. This clock keeps us on the right schedule every day. Our body clock is also called the biological clock and it controls our circadian rhythms, because it repeats every $24 \mathrm{~h}$ [1]. You may be thinking "why $24 \mathrm{~h}$ ?" It is because the daily switch from light to dark tells your body clock what time it is (Figure 1). Your body clock takes this information and sets you to that same time. Let us say that, for some strange reason, the Sun does not come up tomorrow, making it dark for the whole day. Just like the clock on your phone, your body clock can still keep the correct time, even without this change from light to dark. This means that your body clock would still wake you up around 7 a.m., even though it is completely dark outside. Amazingly, this change from light to dark is just one example of an environmental signal that tells your body clock what time it is. Things like food and exercise also send messages to your body to help you keep time (Figure 1) [2]. More interesting facts about your clock are found in Box 1. 


\section{METABOLIZE}

To break down Metabolism consists of reactions in your body that transform the nutrients in food into the energy that your body needs.

\section{DIGESTION}

The way your body gets nutrients and energy from the food you eat.
Box 1 | Fun facts.

1. We know that we have clocks in our bodies because some scientists did a bunch of experiments and discovered them. They won a Nobel Prize for it! What is a Nobel Prize? It is like winning the student of the month award, but for your whole life.

2. Even your poop knows what time it is! You have billions of tiny organisms inside your intestines, where you make your poop. They help you get nutrients into your body. Some of these microorganisms grow at night and others grow during the day.

3. Not just humans have body clocks. All forms of life have evolved with clocks of their own. Fish, birds, trees, worms, flies-they all have some kind of clock. What is your favorite animal? It has a clock!

4. We experience jet lag because of our body's clock. Do you know what jet lag is? If you take a trip to the other side of the world, when you get there you will feel sleepy during the day and wide awake at night. Why? Because your body's clock needs up to a week to adjust your time to the new local time.

\section{WHEN YOU EAT, YOUR BODY CLOCK EATS}

Let us talk about eating. In our laboratory, we use mice to study how food can change the body clock. Food sends messages to your body, helping it stay on schedule [3]. This means that during the day, meals send information, letting the body clock know it is time to turn on "food mode." Once your body clock is in gear, it helps you digest and metabolize your food, using or storing all the energy you need. When digestion is finished, your body clock will go into "standby mode," resting and waiting for the next meal. Most days, you probably eat meals and snacks at about the same times. So, at these times, your body clock will be in food mode. Then, at the times you are not eating (like during the night), your body clock will be able to recharge in standby mode. Now, imagine you go to your best friend's house for a sleepover and you crush a pint of ice cream in the middle of the night. That sounds fun, but your biological clock would not be so happy. Your body clock is supposed to be resting and recharging at this time. If you wake it up at night, the next day it will be sluggish and struggle to do its job. It is ok if this happens every once in a while. But, if you had this midnight ice cream meal every night for a month, you would reset your body clock to food mode at night, which could force it into standby mode during the day-a time when you are supposed to be active and alert. Eating at the right time of day trains your body clock to become stronger.

\section{WHAT YOU EAT, YOUR BODY CLOCK EATS}

Imagine you are at lunch, sliding your tray down the line. Did you grab the chicken sandwich on a wheat bun with green beans, a fruit cup, and carton of milk? Or, did you buy all tasty but mostly unhealthy snacks? Although it might be hard to believe, a delicious lunch of only unhealthy snacks can confuse your body's clock and change how your digestive system and metabolism work (Figure 2) [4]. Let us say you eat unhealthy snacks for breakfast, lunch, and dinner every day for 1 
Figure 2

The food you eat can change your body clock's time. (A) A balanced diet helps your body clock get ready to digest food at the right time, making energy when you need it and storing energy when you do not. (B) An unbalanced diet that is high in fat and sugar can trick your body clock into storing energy when you actually need it and making energy when you do not.
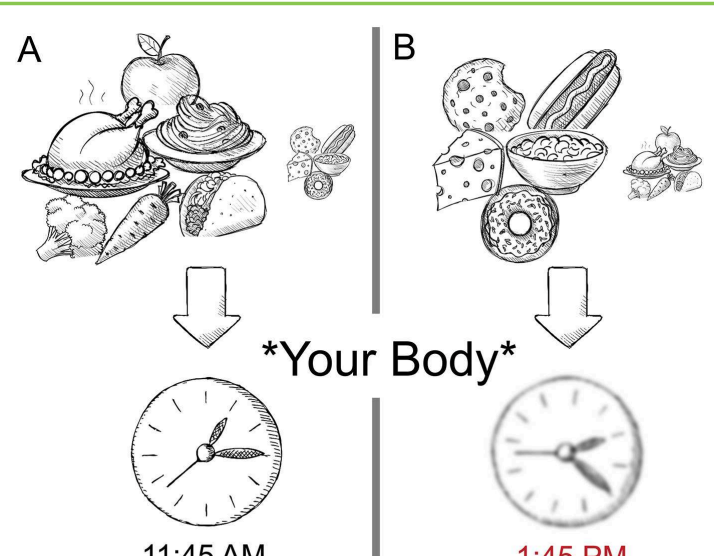

1:45 PM<smiles>C1CCCC1</smiles>

ENERGY

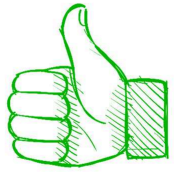<smiles>C1CCCC1</smiles>

FAT STORAGE

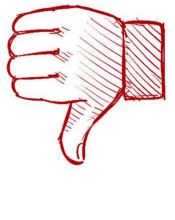

month. Over this time, your body's clock will get confused because it is hit with amounts of sugar and fat that can be damaging to your overall health. Unhealthy nutrients will tell your clock to go into food mode at the wrong time and, as a result, your body clock's time is moved forward, kind of like daylight savings time. This means that your body clock will also switch into standby mode too early and would not be ready to metabolize the food you eat next. Instead of saying, "hey, let us use this food to make energy for the day," your body clock might say, "hey, let us store most of this food as fat for later." This happens because your body clock can sense the types and amounts of nutrients, like sugar and fat, from your meals. So, you can see that your body's clock does more than just help with meal timing-it also helps you digest and metabolize the nutrients from your meals. But do not worry, these scary changes are reversible. You can get your body's clock back to the right time by eating well-balanced meals of whole grains, proteins, fruits, and vegetables. When your body's clock is strong and smart, you can still have one or two unhealthy snacks without a problem.

\section{HOW MANY CLOCKS ARE IN YOUR BODY?}

You actually have many different clocks in your head and body, if you can believe it! [5]. Your organs all do different things for you. Your muscles help you run and pick stuff up, your bones hold you together, your stomach and liver digest your food, and your brain helps you think. These body parts each have a clock of their own, so 
Figure 3

Body clocks talk to each other. (A)

Balanced meals eaten at the right times help your body clocks talk to each other and work together to digest your food. This means that the organs know when to do their jobs. (B) Unbalanced, high-fat/sugar meals confuse your body clocks into not knowing when to do their jobs. This means that they can no longer digest and metabolize your food as a team.

\section{HORMONES}

Small messengers that travel from one organ to another and tell your body what to do.

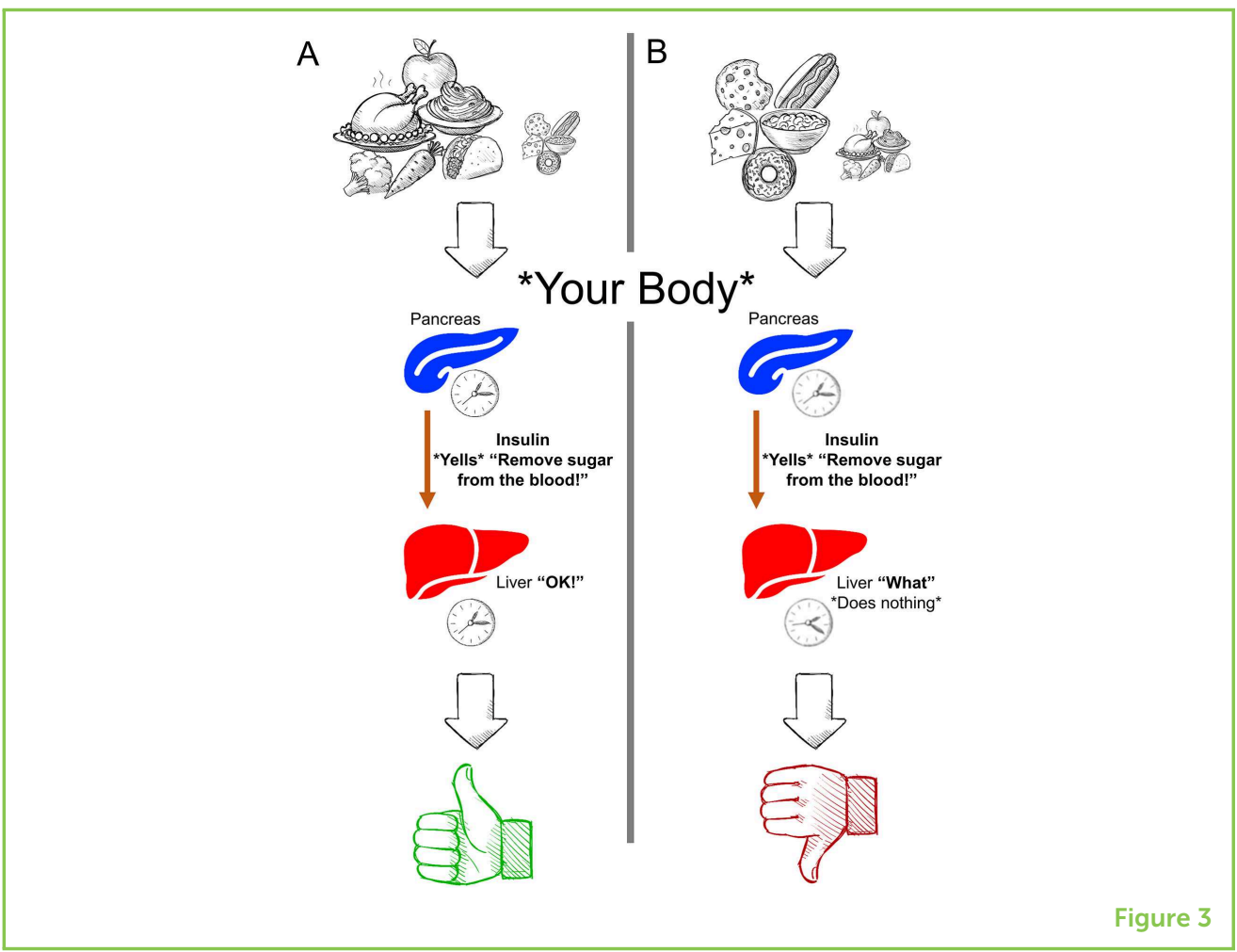

they know when to be active and when to take a break. These clocks are very important, because they help your organs work at their best and also help them work together on the right schedule. Amazingly, each clock can send signals to tell its time to neighboring organs (Figure 3). What are these signals? They can either be hormones or other small molecules [2]. For example, when you eat, your pancreas releases insulin, a hormone that regulates sugar levels in your blood. Insulin tells your liver to take up sugar. When you are not eating, insulin levels go down, which tells your liver to make sugar instead. It is this sending and receiving of signals at different times of the day that allows your body clocks to talk with each other and work together to metabolize nutrients. As we mentioned, an unhealthy diet can interfere with this communication. Unhealthy eating can confuse your organs into not knowing who is doing what and when. Eating a healthy, balanced diet will keep your body clocks talking to each other and working properly.

\section{SUMMARY: KEEP YOUR BODY CLOCKS IN SHAPE}

Besides helping you know when to sleep, your body clocks do much, much more! They tell your body when to feel strong, when it is time to relax, when to increase your body's temperature, when to change your blood pressure, and when you need different levels of hormones (Figure 1). We know many of these things from studying animals, but we have learned that food changes the daily rhythms of humans, as well [6]. To keep our clocks healthy, all we have to do is listen to what 
they are telling us. If it is late at night and you cannot keep your eyes open anymore, you should not try to stay awake just to watch more video on your favorite YouTube channel. You are tired and need rest, so sleep. If you go shopping right after lunch and see a yummy snack, do not eat it yet. Buy it and save it for later when you feel hungry again, when your body needs the nutrients. Your body clocks are very important, helping you be at your best and stay healthy every day. We should all do our best to help our body clocks work well!

\section{ACKNOWLEDGMENTS}

We would like to thank the members of the Sassone-Corsi laboratory for helpful discussion. CG was supported by the European Research Council (ERC MSCA-IF-2016 MetEpiClock 749869).

\section{REFERENCES}

1. Greco, C. M., and Sassone-Corsi, P. 2019. Circadian blueprint of metabolic pathways in the brain. Nat. Rev. Neurosci. 20:71-82. doi: 10.1038/s41583-018-0096-y

2. Dyar, K. A., Lutter, D., Artati, A., Ceglia, N. J., Liu, Y., Armenta, D., et al. 2018. Atlas of circadian metabolism reveals system-wide coordination and communication between clocks. Cell 174:1571-85 e11. doi: 10.1016/j.cell.2018.08.042

3. Asher, G., and Sassone-Corsi, P. 2015. Time for food: the intimate interplay between nutrition, metabolism, and the circadian clock. Cell 161:84-92. doi: 10.1016/j.cell.2015.03.015

4. Eckel-Mahan, K. L., Patel, V. R., de Mateo, S., Orozco-Solis, R., Ceglia, N. J., Sahar, S., et al. 2013. Reprogramming of the circadian clock by nutritional challenge. Cell 155:1464-78. doi: 10.1016/j.cell.2013.11.034

5. Schibler, U., and Sassone-Corsi, P. 2002. A web of circadian pacemakers. Cell 111:919-22. doi: 10.1016/s0092-8674(02)01225-4

6. Gill, S., and Panda, S. 2015. A smartphone app reveals erratic diurnal eating patterns in humans that can be modulated for health benefits. Cell Metab. 22:789-98. doi: 10.1016/j.cmet.2015.09.005

SUBMITTED: 20 June 2019; ACCEPTED: 25 November 2019; PUBLISHED ONLINE: 10 December 2019.

EDITED BY: Suzanne Phelan, California Polytechnic State University, United States

CITATION: Greco CM, Koronowski KB and Sassone-Corsi P (2019) The Body's Clock: Timekeeping With Food. Front. Young Minds 7:141. doi: 10.3389/frym.2019. 00141

CONFLICT OF INTEREST: The authors declare that the research was conducted in the absence of any commercial or financial relationships that could be construed as a potential conflict of interest. 


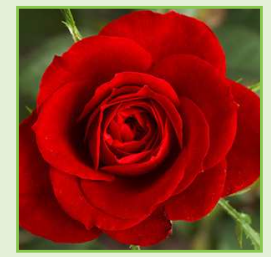

COPYRIGHT @ 2019 Greco, Koronowski and Sassone-Corsi. This is an open-access article distributed under the terms of the Creative Commons Attribution License (CC $\mathrm{BY})$. The use, distribution or reproduction in other forums is permitted, provided the original author(s) and the copyright owner(s) are credited and that the original publication in this journal is cited, in accordance with accepted academic practice. No use, distribution or reproduction is permitted which does not comply with these terms.

\section{YOUNG REVIEWER}

\section{SIENNA, AGE: 15}

I am a 15 years old working my first job at the University of Arizona. That is where I learned about Frontiers for Young Minds. I was asked if I wanted to review this paper, which I accepted as I thought this was a great way for children to learn about complex scientific studies. I value any experience that helps me learn and widen my worldview.
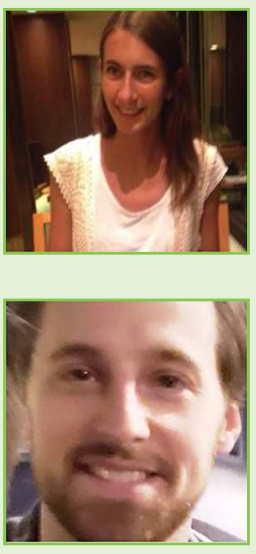

\section{AUTHORS}

\section{CAROLINA M. GRECO}

Carolina joined the Sassone-Corsi lab about 3 years ago after receiving her Ph.D. from the University of Milan. Her main interest is to investigate how metabolic processes affect transcriptional and epigenetic mechanisms. She loves to spend her free time with her two cats Gandalf and Mila.

\section{KEVIN B. KORONOWSKI}

In high school, Kevin adopted his brother's interest in fitness and nutrition. Together, they both played ice hockey and wanted to maximize their potential for sports. The idea of a career in the National Hockey League has long since faded, however, Dr. Koronowski's interest in nutrition and metabolism has stuck with him. Kevin is enthralled by the mechanisms through which environmental cues and dietary interventions regulate the epigenome and impact human health/disease.

\section{PAOLO SASSONE-CORSI}

Paolo is Donald Bren Professor and Director of the Center for Epigenetics and Metabolism at the University of California, Irvine. His research is focused on the link between circadian rhythms, epigenetics, and metabolism. He loves spending time in the lab with his collaborators, being outdoors playing sports and travel to exotic destinations. *psc@uci.edu 